Jurnal Lakon, 8 (1) 2019

(40-49)

\title{
REALITAS KEKERASAN SIMBOLIK DALAM RELASI SOSIAL ANGGOTA ORGANISASI PENCAK SILAT PERSAUDARAAN SETIA HATI TERATE DI KABUPATEN NGANJUK
}

The Reality of Symbolic Violence in the Social Relation of Members of Persaudaraan Setia Hati Terate Organisation Martial Arts in Nganjuk Regency

\author{
Ephrilia Noor Fitriana \\ Magister Kajian Sastra dan Budaya, Fakultas Ilmu Budaya, \\ Universitas Airlangga \\ noor.fitriana0604@gmail.com
}

\begin{abstract}
Abstrak: Tujuan dari penelitian ini adalah untuk menganalisis Realitas kekerasan dalam relasi sosial anggota Organisasi Pencak Silat Persaudaraan Setia Hati Terate di Kabupaten Nganjuk. Penelitian ini menggunakan teori praktik sosial oleh Pierre Bourdieu dengan melihat habitus, modal, arena dan strategi yang dimanfaatkan dalam menghadapi aksi kekerasan berkelompok tersebut. Berdasarkan dari penelitian yang dilakukan, temuan-temuan yang didapat adalah; terdapat habitus-habitus yang dimiliki oleh anggota PSHT yang diimplementasikan dalam bentuk kekerasan simbolik sebagai pemicu terjadinya kekerasan, meliputi pelecehan identitas PSHT; persaingan antara perguruan silat; solidaritas internal dalam kelompok; arogansi kelompok. Selain itu ditemukan bahwa terdapat konversi modal sosial, seperti rasa solidaritas yang tinggi antar anggota dimanfaatkan untuk mendukung adanya kekerasan. Kemudian, ditemukan bahwa terdapat kekerasan simbolik dalam relasi sosial PSHT Nganjuk dengan kelompok lain.
\end{abstract}

Kata-kata Kunci: Kekerasan, PSHT, habitus, modal, arena

\begin{abstract}
This research was conducted with the aim to analyze the reality of violence in the social relations of members of Persaudaraan Setia Hati Terate Organisation Martial arts in Nganjuk Regency. This study uses the theory of social practice by Pierre Bourdieu by looking at the habitus, capital, arena and strategies used in dealing with the action of group violence. Based on the research, the findings include; there are habitus owned by PSHT members that are implemented in the form of symbolic violence as a trigger for violence, including, the abuse of PSHT identity; competition between silat colleges; internal solidarity within the group; group arrogance. Besides, there was a social capital conversion, such as a high sense of solidarity among members used to support the existence of violence. It was also found that social conditions that cause violence between groups PSHT Nganjuk with other groups that occur were the presence of symbolic violence in social relations PSHT Nganjuk with other groups.
\end{abstract}

Keywords: Violence, PSHT, habitus, capital, field

\section{PENDAHULUAN}

Organisasi Pencak Silat Persaudaraan Setia Hati Terate (PSHT) merupakan salah satu representasi olahraga bela diri dari Indonesia, khususnya Jawa Timur. PSHT juga mengajarkan tentang pembangunan karakter yang mencakup nilai ketuhanan, nilai kemanusiaan, dan berbudi pekerti luhur sehingga diharapkan mampu menciptakan pribadi yang selaras antara kecerdasan jasmani dan kecerdasan rohani. Namun, pada kenyataannya saat ini kerap terjadi kekerasan antar kelompok yang melibatkan anggota PSHT Nganjuk. Perselisihan antara PSHT dengan kelompok-kelompok lain semakin menyebar dan terjadi terus menerus. Sehingga realitas kekerasan yang ada 
terkesan dipandang sebagai penyimpangan manifestasi ajaran PSHT yang direproduksi oleh anggota PSHT Nganjuk.

Tahun 2016 lalu, terdapat peristiwa dirobohkannya tugu PSHT di seluruh wilayah Kabupaten Nganjuk. Melalui akun Facebook PSHT INFO yang menjadi media komunikasi bagi warga PSHT seluruh Indonesia, salah seorang warga PSHT membagikan sebuah kabar terkait dengan penghancuran seluruh tugu PSHT Nganjuk oleh Polres Nganjuk. Hal ini tentu memicu amarah Warga PSHT Nganjuk dan sempat terjadi perang argumen di sosial media. Namun kasus tersebut dapat ditutup secara damai dan saat ini tugu PSHT dapat dibangun hampir di setiap kabupaten Nganjuk. seperti di daerah kecamatan Loceret, Kecamatan Sukomoro, Kecamatan Tanjunganom, dll ${ }^{1}$.

Dalam peristiwa kekerasan yang terjadi, kegiatan konvoi atau arak-arakan dan pembangunan tugu-tugu PSHT Nganjuk kerap kali dianggap sebagai pemicu terjadinya kekerasan. Berdasarkan wawancara yang dilakukan oleh peneliti dengan sseorang warga PSHT tingkat II, pada bulan November 2017 lalu terjadi bentrok antara PSHT dengan Pagar Nusa atau PN. Saat kelompok PN dalam perjalanan usai acara sabung bebas ${ }^{2}$, mereka mencoba untuk menghancurkan tugu PSHT di Tanjunganom. Anggota PSHT tidak terima dan akhirnya terlibat bentrok. Kemudian pada tanggal 2 Desember 2017, PSHT ranting Berbek juga terlibat bentrok dengan organisasi Pencak Silat Pagar Nusa usai melaksanakan tasyakuran. Bentrok terjadi akibat pihak dari Pagar Nusa diamdiam melempari batu anggota PSHT saat mereka melakukan arak-arakan (berkendara motor beramai-ramai).

${ }^{1}$ https://www.facebook.com/PSHT.INFO/photos/a.35 $0558191643660.87610 .333908916641921 / 111194236$ $8838568 /$ ?type $=1 \&$ theater

2 Acara bertarung tahunan yang diselenggarakan oleh organisasi pencak Silat Pagar Nusa. Acara ini terbuka untuk umum dan tidak memiliki aturan-aturan serta
Dalam pandangan Bourdieu dikenal dengan istilah Kekerasan simbolik. Kekerasan simbolik merupakan salah satu jenis kekerasan yang tidak terlihat, dalam hal ini biasanya diciptakan untuk membangun suatu stigmatisasi (Rudianto, 2012: 80). Fenomena pembangunan tugutugu PSHT dan kegiatan konvoi dapat dikatakan sebagai salah satu bentuk kekerasan simbolik yang dapat memicu konflik antar kelompok atau aksi kekerasan. Sehingga dalam hal ini dapat dimaknai bahwa peristiwa kekerasan yang terjadi diduga sebelumnya diawali dengan adanya kekerasan simbolik. Dengan adanya fenomena tersebut terdapat penyimpangan manifestasi oleh anggota PSHT Nganjuk. Oleh sebab itu, peneliti bermaksud untuk mencari tahu bagaimana kekerasan simbolik tersebut dapat terbentuk oleh anggota PSHT Nganjuk. Maka dalam penelitian ini perlu untuk mengkaji praktik realitas kekerasan anggota organisasi Pencak Silat PSHT Nganjuk meliputi modal, habitus, strategi, arena, agen, dst.

Maka dari itu, penelitian ini memanfaatkan teori Praktik Sosial berdasarkan perspektif Pierre Bourdieu untuk mengkaji dan mengidentifikasi realitas kekerasan simbolik, praktik kekerasan simbolik, serta kondisi sosial anggota PSHT di Kabupaten Nganjuk. Peneliti juga akan meminjam teori solidariats sosial dari Emile Durkheim tertkait tentang jenis solidaritas yang dimiliki oleh anggota PSHT untuk mengetahui apakah solidaritas yang digunakan merupakan bentuk solidaritas yang murni dari hati diri sendiri atau solidaritas yang hanya berdasarkan pada kepentingan kelompok semata.

syarat-syarat tertentu saat bertarung. Setelah bertarung, seluruh peserta diminta untuk makan bersama. Tujuan dari acara ini adalah mempererat tali silaturahmi sebagai makna dari kata "DI ATAS LAWAN DI BAWAH KAWAN". 
Anggraeni (2014) menyatakan bahwa teori Bourdieu dapat digunakan untuk menganalisis dimensi kuasa dan perubahan-perubahan sosial yang terjadi di kalangan masyarakat. Menurut Bourdieu, kuasa dibentuk melalui aspek kultural dan simbolik yang dilegitimatsi secara terus menerus dalam proses interaksi sosial antara agen sosial dengan struktur sosial (Anggraeni, 2014: 27).

Wardani (2012) mengungkapkan bahwa dalam praktik sosial Bourdieu pada dasarnya dipengaruhi oleh tindakantindakan sosial yang dilakukan oleh agen sosial melalui improvisasi tertentu sebagai hasil dari proses interaksi dalam suatu ranah sosial. Agen atau individu merupakan bagian dari integral dari dunia sosial. Dunia sosial adalah tempat di mana agen tumbuh dan kemudian berkontestasi untuk mendapatkan pengakuan kultural, peran, dan identitas sosial (Wardani, 2012: 8). Praktik sosial merupakan integrasi antara habitus dikalikan modal dan ditambahkan ranah. Praktik sosial dapat dirumuskan sebagai beikut: (Habitus $\mathrm{x}$ Modal) + Ranah $=$ Praktik (Adib, 2012: 107).

\section{METODE PENELITIAN}

Penelitian ini memanfaatkan metode kualitatif berupa observasi partisipatif (participatory observation) untuk memahami kondisi atau situasi di lapangan secara langsung oleh peneliti. Penelitian ini juga menggunakan metode wawancara mendalam (indepth interview) dan tidak terstruktur

(unstructured interview).Lokasi penelitian ini berada di padepokan pusat yang terletak di desa Bogo Kidul, kecamatan Bogo, kabupaten Nganjuk. Data dari penelitian ini berasal dari hasil wawancara peneliti dengan informan. Informan tersebut adalah 1 warga PSHT tingkat II, 1 pelatih PSHT ranting Bogo, dengan masing-masing usia di atas 40 tahun. Kemudian, 5 anggota dari PSHT Nganjuk yang sudah disahkan menjadi warga PSHT yang merupakan kerabat dari pelaku kekerasan atau memahami kondisi perselisihan yang terjadi.

Usia dari informan-informan tersebut sekitar 15 hingga 22 tahun. Untuk menghindari percakapan di luar konteks, peneliti membuat pedoman wawancara atau interview guide. Tahap pertama untuk menganalisis data yaitu data-data dari hasil wawancara dan dokumentasi yang didapat oleh peneliti tersebut akan dibaca secara keseluruhan dan mendalam. Tahap kedua yaitu peneliti mengidentifikasi dan menjabarkan akar-akar pemicu terjadinya kekerasan serta fakta-fakta lain yang berkaitan dengan kasus kekerasan PSHT. Kemudian peneliti mencari norma-norma budaya yang muncul untuk kemudian dianalisis menggunakan perspektif budaya dengan teori Praktik Sosial milik Pierre Bourdieu untuk melihat agen dari PSHT yang terlibat kekerasan, modal yang dimilki, habitus dari agen tersebut, strategi yang dilakukan, dsb. Tahap terakhir adalah peneliti melakukan pemaknaan mendalam dari analisis yang sudah dilakukan.

\section{HASIL PEMBAHASAN \\ Kekerasan Simbolik sebagai Habitus anggota PSHT}

Dalam penelitian ini ditemukan habitus yang diimplementasikan dalam wujud kekerasan simbolik pada anggota PSHT Nganjuk ini. Berdasarkan dari data-data yang telah ditunjukkan, peneliti mengidentifikasi kekerasan simbolik pada anggota PSHT terdiri dari, pelecehan identitas PSHT; persaingan antara perguruan silat; solidaritas internal dalam kelompok; arogansi kelompok.

\section{Pelecehan Identitas}

Pelecehan identitas ini dapat dikaitkan dengan penodaan lambang atau atribut PSHT. Seperti yang ditunjukkan melalui hasil wawancara berikut, berdasarkan dari hasil wawancara peneliti dengan keenam informan yang ada, sebagian besar dari mereka menyatakan bahwa kasus bentrok 
sering mengaitkan dengan atribut-atribut miliki PSHT. Kasus perkelahian satu lawan satu antar PSHT dan PN di Kertosono mengakibatkan kain mori duplikat milik warga PSHT dicuri. Kemudian, pada kasus lain tugu PSHT dirusak oleh perguruan silat lain saat melakukan arak-arakan, lambang "hati" yang dijiplak oleh perguruan silat Pagar Nusa, dll.

Dalam perspektif Bourdieu mengenai konsep kekerasan simbolik, pada dasarnya eksistensi suatu konflik dalam kelompok juga disertai dengan kekerasan non-fisik. Kekerasan tersebut dilakukan dengan cara penyerangan simbolik terhadap lawan melalui perantara-perantara tertentu. Rudianto mengungkapkan bahwa kekerasan simbolik merupakan salah satu jenis kekerasan sosial di mana kekerasan tersebut ditunjukkan secara tidak kasat mata atau tidak melalui fisik, atau disebut juga dengan kekerasan secara terstruktur dan bersifat kultural. Kekerasan simbolik ini mampu menciptakan diskriminasidiskriminasi secara psikis (Rudianto, 2012: 80). Dalam kasus ini, penodaan lambang PSHT merupakan salah satu bentuk kekerasan simbolik yang dapat memicu adanya kekerasan antar kelompok PSHT dengan kelompok lain. Pada dasarnya, hal-hal yang berkaitan dengan lambang dan atribut-atribut PSHT dianggap sebagai benda yang sakral dan menjadi identitas dari anggota PSHT itu sendiri di mana terdapat unsur-unsur yang bersifat spirituil sebagai pembentuk jati diri serta kepribadian mereka, terutama nilai-nilai tentang ke-Tuhanan. Terlebih untuk mendapatkan lambang dan atribut tersebut diharuskan untuk mengikuti serangkaian ritual-ritual tertentu seperti pengesahan ${ }^{3}$. Sehingga tidak dapat disangkal bahwa lambang atau atribut yag berkenaan dengan PSHT dianggap sebagai benda yang esensial bagi para anggota PSHT.

\footnotetext{
${ }^{3}$ Penges ahan merupakan sebuah ritual wajib yang dilakukan oleh organisasi pencak silat PSHT untuk meresmikan siswa-siswa PSHT menjadi anggota atau
}

\section{Persaingan Antar Kelompok}

Dalam pemikiran Pruitt dan Rubin (1998) konflik dipandang sebagai sebuah pertentangan serta keinginan atau tujuan yang berbeda. Keinginan atau tujuan tersebut biasanya berupa suatu kekuasaan. Dalam proses mendapatkan kekuasaan tersebut selalu disertai dengan adanya persaingan dan pertarungan yang disebut dengan istilah pertarungan kekuasaan atau struggle of Power sehingga meraka dapat berada pada posisi yang mapan (Syawaludin, 2014: 4). Perkelahian satu lawan satu atau dikenal dengan istilah sambung dalam PSHT merupakan salah satu wujud persaingan yang ditujukan untuk mengetahui siapa yang terbaik. Tentu dalam hal ini berkaitan dengan kekuasaan, "siapa yang menang, dia yang berkuasa". Pertarungan atau persaingan dalam kelompok dianggap menjadi komponen yang selalu ada dalam setiap konflik.

Sambung pada dasarnya merupakan sebuah praktik bertarung menggunakan jurus yang dilakukan oleh dua orang yang mana praktik ini digunakan dalam menghadapi musuh (Sutoyo, 2014: 337). Dalam setiap kelompok perguruan silat, praktik sambung dianggap sebagai suatu kegiatan yang biasa dan diajarkan dalam kelompok tersebut sebagai wujud pertahanan diri ketika terancam oleh musuh. Menantang atau menerima tantangan sambung dipandang sebagai sesuatu yang tidak dapat dihindari.

\section{Solidaritas Internal dalam Kelompok}

Dalam PSHT juga ditanamkan rasa tali persaudaraan serta solidaritas yang tinggi pada sesama anggotanya. Hal tersebut diajarkan sejak pertama kali anggota PSHT mengikuti organisasi ini. Selain itu, PSHT juga memberikan ajaran tentang budi pekerti luhur yang dapat diterapkan dalam kehidupan sehari-hari terutama yang

bagian dari PSHT secara sah. Biasanya siswa yang sudah sah menjadi anggota PSHT tersebut disebut sabagai "warga". 
berhubungan dengan rasa saling mengasihi antar sesama. Dalam Persaudaraan Setia Hati Terate ini familiar dengan istilah dari nilai luhur kehidupan dari kebudayaan Jawa yaitu "Memayu Hayuning Bawono". Memayu artinya membuat hidup atau indah, hayu berarti ayu/ indah atau cantik, Bawana artinya dunia atau jagad. Makna dari istilah tersebut adalah sebagai umat manusia kita wajib untuk menjaga keamanan dan ketentraman dalam dunia sehingga nyaman untuk dihuni.

Habitus dapat dikaitkan dengan nilainilai, watak, gaya hidup yang dikonstruksi secara dini yang diharapkan dapat memposisian seseorang atau kelompok ke dalam tatanan sosial yang baik. Habitus berkembang melalui pengalaman individu secara terus menerus selama ia berinteraksi dengan masyarakat (Haralambos dan Holborn, dalam Juliandro, 2017: 5). Setiap anggota PSHT dibekali dengan nilai budaya tertentu untuk menumbuhkan rasa persaudaraan dan kasih sayang yang kuat terhadap sesama anggota.

\section{Arogansi Kelompok}

Menurut pandangan Coser konflik yang terjadi secara berkelompok atau communal conflicts disebabkan karena adanya faktorfaktor, seperti, identitas budaya dari kelompok tersebut dan sumberdaya yang dimiliki. Konflik secara berkelompok ini juga sering menyebar hingga ke persoalan teritorial apabila konflik tersebut berkaitan dengan identitas kawasan (Syawaludin, 2014: 10). Kuantitas yang banyak menandakan adanya power atau kuasa yang membuat pihak lawan merasa tersisihkan. Ditambah lagi dengan pemakaian atribut PSHT yang mana menunjukkan identitas kelompok tersebut tentunya mampu menumbuhkan kecemburuan bagi kelompok lain yang dianggap sebagai saingannya.

\section{Pembangunan Tugu-tugu PSHT di Wilayah Nganjuk}

Pembangunan tugu-tugu PSHT sebenarnya bukanlah kegiatan yang wajib dilakukan oleh kelompok PSHT, namun hal tersebut pada kenyataannya dilakukan oleh sebagian besar anggota PSHT hampir di seluruh Indonesia dan seakan sudah menjadi budaya bagi kelompok organisasi PSHT. Pasalnya juga tidak terdapat larangan pemerintah terkait dengan kegiatan tersebut. Gambar 1 dan 2 merupakan gambar-gambar pembangunan

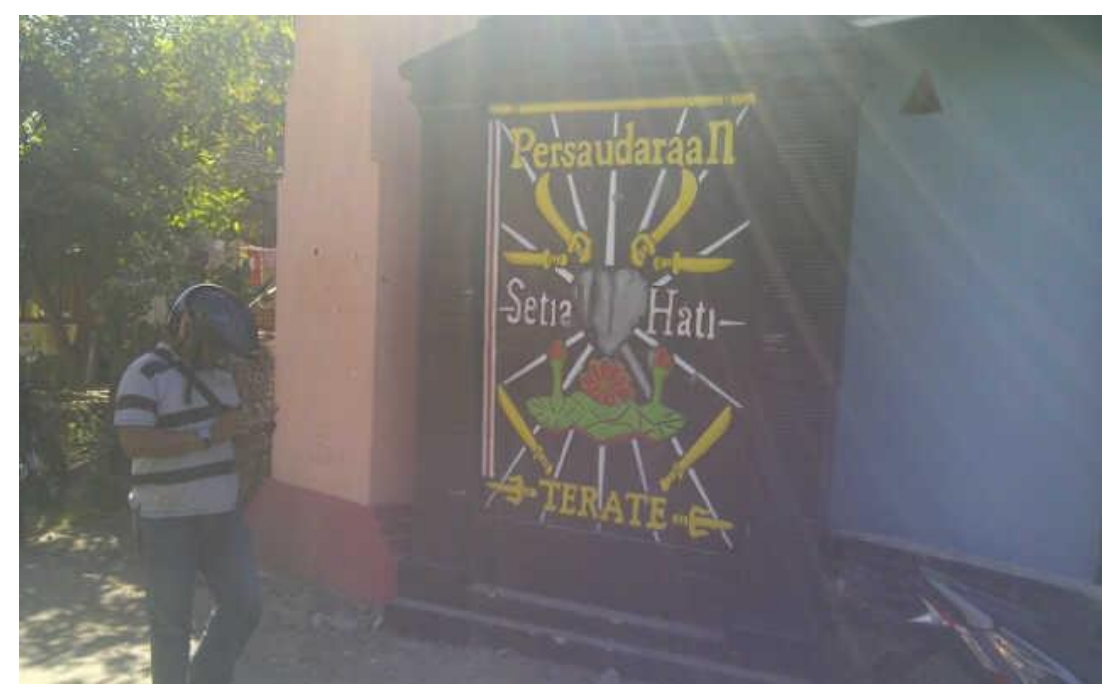

Gambar 1. Tugu PSHT di rayon Ngadiboyo ranting Rejoso, Nganjuk

Sumber: https://www.adakitanews.com/tugu-psht-dirusak-preman-sebelas-pemuda-diamankan/ 
tugu PSHT yang yang tersebar di wilayah Kabupataen Nganjuk.

Pembangunan tugu yang dilakukan oleh anggota PSHT dalam jumlah masa yang banyak inilah yang disebut dengan doxa. Kegiatan-kegiatan tersebut merefleksikan tanda-tanda simbolik yang dianggap wajar-wajar saja dilakukan dan dilegitimasikan oleh kelompok PSHT sendiri sebagai wujud kebanggaan organisasi pencak silat PSHT. Tanpa disadari hal tersebut juga menandai adanya dominasi wilayah yang dapat mendiskriminasi bagi pihak lain di luar PSHT, di mana mereka merasa tereksklusi dari wilayah tersebut. Kemudian lambat laun memunculkan kecemburuan dan memicu terjadinya perselisihan. Tahap selanjutnya akan muncul pihak-pihak yang terdominasi untuk melakukan perlawanan atau yang disebut dengan heterodoxa dengan cara merusak tugu-tugu tersebut. Hingga pada akhirnya menyebabkan aksi kekerasan yang melibatkan masa yang mendukung orthodoxa dan yang tidak mendukung heterodoxa.

\section{Modal Anggota PSHT \\ Solidaritas Sebagai Modal Sosial}

Solidaritas atau tali persaudaraan menjadi senjata bagi kelompok PSHT untuk mempertahankan eksistensinya dalam kelompok sosial khususnya di Nganjuk ini. Terutama dalam mengahadapi konflik antar kelompok, kekuatan kelompok sangat diperlukan. Dengan memanfaatkan kesolidaritas antar anggota, PSHT dianggap sebagai kelompok yang dapat mengancam eksistensi kelompok lain. Dalam pemahaman secara dasar, modal dikaitkan dengan nilai simbolik, seperti otoritas dan status (Adib, 2012: 107). Dari klasifikasi modal itu sendiri, solidaritas dimasukkan dalam jenis modal sosial. Sebagaimana Bourdieu mengungkapkan bahwa modal sosial dapat berupa jaringan sosial, relasi terhadap seseorang atau kelompok tentunya di lingkungan sekitar (Bourdieu, 1980: 32).

Kesolidaritasan hanya dimiliki kelompok perguruan pencak silat PSHT. Hal ini kemudian sekaligus menjadi pembeda bagi anggota PSHT dalam persaingannya dengan perguruan silat lain maupun kelompok lain. Dalam perspektif Bourdieu kondisi tersebut dikaitkan dengan konsep perbedaan atau distinction. Distinction dalam pemikiran Bourdieu diartikan sebagai aspek pembeda yang sangat signifikan untuk menunjukkan adanya hubungan dominasi (Kartikawati, dkk, 2014: 7). Modal kesolidaritasan yang dimiliki oleh PSHT dijadikan sebagai pembeda yang kemudian memunculkan dominasi tertentu di mana solidaritas tersebut selalu digunakan sebagai kekuatan bagi PSHT dalam menghadapi setiap kasus kekerasan yang terjadi.

\section{Mobilisasi Massa Sebagai Modal Sosial}

Selain memiliki jiwa solidaritas yang kuat, PSHT memiliki anggota yang meningkat tiap tahunnya. Hal ini dapat dilihat melalui jumlah keseluruhan warga PSHT Nganjuk yang disahkan setiap tahun. Pada tahun lalu 2017, PSHT Nganjuk telah mengesahkan warga sebanyak 2615 orang, tahun sebelumnya, 2016, sebanyak 1995 orang. Tahun 2015 anggota yang disahkan sebanyak 1668, sedangkan pada tahun 2014 terdapat sebanyak 1767 orang yang disahkan menjadi anggota PSHT secara sah. Total keseluruhan warga PSHT di seluruh kabupaten Nganjuk adalah 46138 orang 4 . Kondisi di mana PSHT memiliki jumlah yang banyak serta jaringan yang luas di setiap lapisan masyarakat merupakan modal sosial yang dapat dimanfaatkan oleh kelompok PSHT untuk

\footnotetext{
4 Berdasarkan dari data Kesekretariatan Organisasi pencak silat PSHT cabang Nganjuk.
} 
mendapatkan legitimasi di kalangan masyarakat.

\section{Prestasi Sebagai Modal Budaya}

Kemampuan anggota PSHT dalam bersilat terbilang baik. Juara umum Dandim Cup Nganjuk 2018 diraih oleh PSHT. Pada tahun 2017 lalu, dari 211 atlit silat, sekitar 150 di antaranya merupakan anggota dari PSHT Nganjuk ${ }^{5}$. PSHT setiap tahunnya mengadakan Krida Tanding Silat PSHT kabupaten Nganjuk yang mana pertandingan ini memperebutkan piala bupati cup. Tujuan diadakannya acara tersebut adalah untuk mencari talentatalenta baru yang berpotensi dan berbakat agar dapat mewakili ajang kompetisi yang lebih tinggi 6 .

Dalam hal ini, kelompok PSHT juga memiliki modal budaya untuk mendukung mereka mendapat posisi yang cukup menjanjikan di mata masyarakat khususnya Nganjuk. Dilihat dari keikutsertaannya yang cukup aktif dalam setiap kompetisi pencak silat yang ada. Media yang memberitakan tentang hal tersebut merupakan sebuah pengakuan yang dapat ditunjukkan kepada masyarakat terkait dengan kemampuan beladiri mereka. Modal budaya atau disebut juga dengan modal simbolik merupakan kemampuan, keterampilan, pengetahuan, tingkat pendidikkan yang dimiliki oleh tiap individu. Modal tersebut dapat digunakan seseorang untuk mencapai tujuan tertentu atau bahkan kedudukan tertentu. Biasanya modal ini juga disertai dengan adanya sebuah pengakuan (Juliandro, 2017:11).

\section{Agen dalam Konflik Kekerasan Simbolik Anggota PSHT}

Agen adalah objek sosial yang memiliki kemampuan dalam memahami, mengendalikan dan menyesuaikan tindakannya berdasarkan arena yang

\footnotetext{
5 http://harianbhirawa.com/2017/07/atlet-silat-psht-
} dominasi-kejuaraan-dandim-cup/. ditinggalinya (Karnanta, 2013: 9). Posisi agen ini bergantung pada besarnya modal dan keseluruhan modal yang dimilikinya (Jawiah, 2017: 28). Agen dalam kelompok PSHT ini terutama yang terlibat dengan kekerasan yaitu anggota dari organisasi pencak silat PSHT yang sudah disahkan serta yang belum disahkan secara resmi menjadi warga dengan kisaran usia remaja yang menduduki bangku SMA. Sebagian besar dari mereka adalah warga pengikut PSHT garis keras. Mereka cenderung merasa memiliki kemampuan yang lebih terutama dalam ilmu bela diri sehingga timbul sifat sombong dan ingin selalu merasa menang dalam setiap hal. Mereka masih dalam proses pembentukan jati diri dan emosi yang cenderung masih labil.

\section{Arena dalam Praktik Kekerasan Simbolik Anggota PSHT}

Arena yang tampak adalah dalam setiap kasus kekerasan yang ada, anggota PSHT cenderung menggunakan modal sosial seperti jumlah masa dari anggota PSHT dan solidaritas. Selain perihal kekerasan, modal sosial seperti solidaritas dan jumlah anggota yang banyak dimanfaatkan untuk tindakan partisipatif dengan cara membangun tugu-tugu PSHT hampir di setiap wilayah Kabupaten Nganjuk. Alihalih untuk menunjukkan identitas serta eksistensi mereka tanpa harus melalui aksi kekerasan atau perkelahian, mereka mendirikan tugu-tugu di setiap tempat sebagai makna bahwa dalam wilayah tersebut didominasi oleh anggota PSHT.

Seperti yang diungkapakn oleh Megasari dan Prasetyo (2017) bahwa arti dari pendirian tugu-tugu yaitu merupakan simbol dari masyarakat sekitar yang tinggal di tempat tersebut sebagian besar adalah warga PSHT. Pembangunan tugu dilakukan dengan inisiatif dan partisipasi bersama dari para warga PSHT tanpa melibatkan organisasi perguruan silat (Budiarto dkk, 2017: 18). Arena pada

6 http://www.matakamera.net/2017/04/krida-tandingajang-menjaring-talenta.html. 
dasarnya berkaitan dengan persaingan mendapatkan sebuah posisi yang dilakukan agen-agen melalui strategistrategi yang dimiliki. Dalam hal ini posisiposisi pada setiap agen dapar berubahberubah sesuai dengan bagaimana agen tersebut mengatur strategi (Karnanta, 2013: 5). Dari gambar di atas merupakan bukti bahwa terjadi persaingan dominasi wilayah antar perguruan silat. Pembangunan tugu lambang perguruan silat tidak hanya dilakukan oleh kelompok PSHT saja, melainkan setiap perguruan silat khususnya di wilayah Nganjuk.

\section{Strategi Sosial Anggota PSHT dalam Praktik Kekerasan}

Strategi anggota PSHT dalam menghadapi praktik kekerasan antar kelompok pada dasarnya adalah dengan memanfaatkan rasa persaudaraan dan solidaritasnya untuk mempersatukan mereka dan dapat bersinergi. Dengan bersama-sama mereka akan memiliki jumlah yang banyak dan menjadi kelompok yang kuat. Dengan demikian, kemungkinan untuk menang akan lebih besar. Dalam setiap kasus kekerasan yang terjadi, pada umumya sering melibatkan kelompok atau masa yang banyak. Hal ini dilakukan dengan tujuan untuk memberikan efek jera pada lawan agar mereka tidak semena-mena pada PSHT. Bila terdapat salah satu dari anggota PSHT menjadi korban, hampir seluruh anggota PSHT akan bergerak dan menindaklanjuti aksi tersebut.

Modal solidaritas yang dimiliki oleh kelompok PSHT ini dimanfaatkan agar mereka memiliki pendukung yang banyak. Hal ini mampu membuat kelompok tersebut menjadi dominan dan berada pada posisi yang aman. Strategi pada umumnya dihubungkan dengan bagaimana seorang individu atau agen dapat memanfaatkan, memberdayakan dan mengembangkan modal yang ada, proses ini dinamakan sebagai strategi reproduksi (Haryatmoko, dalam Karnanta, 2013: 6). Dalam pembahasan lebih jauh
Bourdieu membahas tentang istilah strategi rekonversi modal di mana istilah tersebut adalah kemampuan agen dalam mengoperasikan atau mendistribusikan modal-modal miliknya menjadi modalmodal tertentu yang dapat digunakan dalam suatu arena (Karnanta, 2013: 6).

\section{SIMPULAN}

Berdasarkan dari penelitian tentang realitas kekerasan simbolik dalam relasi sosial anggota organisasi Persaudaraan Setia Hati Terate khususnya di Kabupaten Nganjuk, temuan yang didapatkan adalah sebagai berikut, pertama, terdapat habitushabitus yang dimiliki oleh anggota PSHT yang diimplementasikan dalam bentuk kekerasan simbolik sebagai pemicu terjadinya kekerasan, meliputi pelecehan identitas PSHT; persaingan antara perguruan silat; solidaritas internal dalam kelompok; arogansi kelompok. Pelecehan identitas berkaitan dengan penodaan lambang dan atribut-atribut terkait dengan PSHT.

Pada dasarnya, habitus yang termanifestasikan melalui kekerasan simbolik tersebut cenderung memberikan suatu gertakan atau teror kepada kelompok lain. Sehingga dapat dimaknai bahwa kekerasan simbolik tersebut menunjukkan adanya dominasi-dominasi tertentu yang dikonstruksikan dan mampu membawa kelompok PSHT berada pada posisi yang mapan. Dominasi-dominasi tersebut dikonstruksikan melalui jumlah massa yang masif, klaim daerah kekuasaan serta solidartas yang kemudian mampu memunculkan suatu pengakuan sebagai kelompok yang besar atau berkuasa di dalam wilayah tersebut.

Selain itu ditemukan bahwa terdapat konversi modal sosial, seperti rasa solidaritas yang tinggi antar anggota dimanfaatkan untuk mendukung adanya kekerasan. Keinginan untuk mendukung atau membantu sesama anggota PSHT tidak serta merta berasal dari ketulusan diri sendiri, namun karena berbagai hal di 
antaranya, perasaan segan, kekhawatiran untuk dikucilkan dan faktor ikut-ikutan. Sehingga Solidaritas yang berlaku merupakan solidaritas mekanik di mana rasa mendukung terhadap aksi didasari dengan kepentingan kelompok atau ikutikutan.

Kemudian, dalam penelitian ini juga ditemukan bahwa kondisi sosial yang menyebabkan kekerasan antar kelompok PSHT Nganjuk dengan kelompok lain dapat terjadi adalah adanya kekerasan simbolik dalam relasi sosial PSHT Nganjuk dengan kelompok lain. Pembangunan tugu-tugu serta budaya konvoi di jalan raya yang dilakukan setelah pengesahan atau doa bersama dapat menciptakan legitimasilegitimasi baru yang memrepresentasikan kekuasaan secara simbolik dan tentu dapat memicu terjadinya kekerasan berkelompok. Pembangunan tugu dan kegiatan konvoi di jalan raya sesungguhnya tidak diajarkan dalam PSHT. Namun pada kenyataannya, hal tersebut dilegitimasi sendiri oleh kelompok PSHT sebagai wujud kebanggan terhadap organisasi PSHT dan secara tidak langsung dimaknai sebagai klaim wilayah kekuasaan.

\section{DAFTAR PUSTAKA}

Adib, Muhammad. 2012. Agen dan Strukstur dalam Pandangan Pierre Bourdieu. Jurnal BioKultur Vol. 1 No. 2, Juli-Desember 2012.

Anggraeni, Disna Puspita. 2014. Budaya Arisan dalam Perspektif Bourdieu: Studi Kelompok Arisan Perempuan Kelas Menengah di Surabaya. Surabaya: Fakultas Ilmu Budaya Universitas Airlangga.

Bourdieu, Pierre. 1980. The Logic of Practice. Standford: Standford University Press.

Bourdieu, Pierre. 2011. Choses Dites; Uraian dan Pemikiran. Bantul: Kreasi Wacana.
Bourdieu, Pierre. 2015. Arena Produksi Kultural: Sebuah Kajian Sosiologi Budaya. Bantul: Kreasi Wacana.

Budiarto, Arief dkk. 2017. Peran Pemerintah Kota Madiun dalam Penanganan Konflik Perguruan Silat Persaudaraan Setia Hati Terate dan Perguruan Silat Persaudaraan Setia Hati Winongo Tunas Muda. Universitas Pertahanan Indonesia: Jurnal Prodi Damai dan Resolusi Konflik Vol. 3 No.1, 2017.

Haryatmoko. 2015. Membongkar Rezim Kepastian Pemikir Kritis PostStrukturalist. Yogyakarta: Boekoe Tcap Petroek.

Hasfi, Nurul. 2011. Kekerasan Simbolik terhadap Suku Jawa dalam Program TV "Hidup Ini Indah" di Trans TV. Diunduh pada 16 April 2018, dari http://eprints.undip.ac.id/33025/ 1/Kekerasan_Simbolik_atas_Suku_J awa_dalam_Program_TV_lengkap.p df.

Jawiah, Khalimatus. 2017. Manabus Purih: Praktik Tradisi Jujuran Urang Banjar di Kecamatan Amuntai Utara Kabupaten Hulu Sungai Utara Kalimantan Selatan. Surabaya: Fakultas Ilmu Budaya Universitas Airlangga.

Juliandro, Hari. 2017. Keberadaan Silat Pangean Sebagai Perwujudan Budaya Daerah di Desa Simandolak Kecamatan Benai Kabupaten Kuantan Singingi. Pekanbaru: Jurnal Online Mahasiswa (JOM) Fisip Vol. 4 No. 1, Februari 2017.

Karnanta, Kukuh Yudha. 2013. Paradigma Teori Arena Produksi Kultural Sastra: Kajian Terhadap Pemikiran Pierre Bourdieu. Universitas Gadjah Mada. Yogyakarta: Jurnal Poetika Vol. 1 No. 1, Juli 2013.

Kartikawati, dkk. 2014. Analisis Konsep Distinction Pierre Bourdieu dalam Pemilihan Sekolah Berlabel Islam di Surakarta. Surakarta: Fakultas 
Keguruan dan Ilmu Pendidikan

Universitas Sebelas Maret.

Nuryanto, M. Rahmat Budi. 2014. Studi

Tentang Solidaritas Soisla di Desa

Modang Kecamatan Kuaro

Kabupaten Paser (Kasus Kelompok

Buruh Bongkar Muatan).

Samarinda: eJournal Ilmu Sosiatri

Universitas Mulawarman Vol. 2, No.

3, 2014.

Rudianto, Yayan. 2012. Fenomena

Kekerasan Sosial dan Struktur

Majemuk Masyarakat Indonesia.

Jurnal AKP Vol. 1 No. 1, Februari 2012.

Santoso, Slamet dan Harsono, Jusuf. 2014.

Pola Solidaritas Kelompok Pedagang

Angkringan di Kota Ponorogo.

Ponorogo: Jurnal Sosio Humaniora

Universitas Muhammadiyah

Ponorogo Vol. 16 No. 1, Maret 2014.

Sutoyo. 2014. Integrasi Tasawuf dalam

Tradisi Kejawen Persaudaraan Setia

Hati Terate. Jurnal Tasawuf dan

Pemikiran Islam Sekolah Tinggi

Agama Islam Negeri pnorogo Vol. 4

No. 2, Desember 2014.

Syawaludin, Mohammad. 2014. Memaknai

Konflik dalam Perspektif Sosiologi

Melalui Pendekatan Konflik

Fungsional. Palembang: Fakultas

Adab dan Budaya Islam UIN Raden Fatah.

Wardani, A. K. 2012. Praksis Masyarakat terhadap Kesehatan Kehamilan, Persalinan, dan Nifas di Desa Temoran Kabupaten Sampang (Analisis Pierre Bourdieu. Surabaya: Fakultas Ilmu Budaya Universitas Airlangga. 